\title{
Uitbraak van portfoliose?
}

Het portfolio zien we vaak als het instrument waarin veel nieuwe ontwikkelingen zoals CanMEDS-rollen, competenties, reflectie en (korte) klinische beoordelingen al dan niet terecht een plaats kunnen krijgen. Het wekt dan ook geen verbazing dat vrijwel alle initiële opleidingen en verschillende vervolgopleidingen driftig begonnen zijn met het ontwikkelen van hun eigen portfolio. Is dit een modieuze trend? Het lijkt wel op een uitbraak van portfoliose!

De manier waarop het portfolio gebruikt wordt, varieert. De variatie betreft zowel de inhoud van het portfolio als de manier waarop de beoordeling plaatsvindt. Niet altijd dekt de term 'portfolio' de onderwijskundige lading. ${ }^{1}$

Om te beginnen is de onderwijskundige functie van een portfolio tweeërlei. ${ }^{2}$ Het portfolio is aan de ene kant een leerinstrument dat studenten aanzet tot het reflecteren op (praktische) ervaringen. Aan de andere kant is het een toetsinstrument. Er zijn onderwijskundigen die vinden dat deze twee functies van het portfolio niet kunnen samengaan en dat men een duidelijke keuze moet maken voor een van beide functies. Meestal kiezen de voorstanders van deze redenering voor het portfolio als leerinstrument. Zij betogen dat studenten het portfolio anders zullen gaan gebruiken als hun ingeleverde werk getoetst moet worden. ${ }^{3}$ Aan de andere kant wordt beargumenteerd dat wanneer het werk van een student niet beoordeeld wordt, de sturende functie überhaupt niet in werking treedt. ${ }^{4}$ Mijn opvatting is dat de ene functie niet zonder de andere kan.
Dat het twee kanten van dezelfde medaille zijn. En dus is het voor ons als onderwijsontwikkelaars een uitdaging om de juiste combinatie van beide functies te vinden, zodat het leren optimaal gestimuleerd wordt.

Over de inhoud van een portfolio zijn de meningen ook verdeeld. Bij onderwijsportfolio's geven we vaak tevoren aan wat er aan het eind van een bepaalde periode in het portfolio opgenomen moet zijn. Bijvoorbeeld uitgewerkte opdrachten, een $\mathrm{x}$-aantal korte klinische beoordelingen en (zelf-)reflecties. Het portfolio is echter meer dan een logboek waarin van alles wordt afgevinkt. De vraag is dan ook hoe sterk de tevoren oplegde structuur moet zijn. Waar ligt de eigen verantwoordelijkheid voor de student? Omdat reflectie een belangrijk onderdeel van een portfolio is, moet ook duidelijk zijn waarop gereflecteerd moet worden. Voordat studenten gevraagd worden te reflecteren, moeten ze wel in de gelegenheid gesteld worden om zinvolle praktijkervaringen op te doen waarop ze kunnen reflecteren, opdat ze er iets van leren.

Ook op het terrein van de begeleiding en de beoordeling ligt er nog een aantal vragen. Wie doet de begeleiding? Waaruit bestaat de begeleiding? Hoe vaak moet de begeleiding plaatsvinden. Zijn voor het begeleiden speciale vaardigheden nodig? Is de begeleider dezelfde als de beoordelaar? Wat wordt er nu precies beoordeeld en waar wordt een student op afgerekend? Kan een zelfreflectie eigenlijk wel onvoldoende zijn? En variëren deze onderwerpen per studie- en ontwikkelingsfase? In 
de reeds beschikbare literatuur staat te lezen dat een portfolio globaal beoordeeld moet worden en dat de beoordeling van portfolio eerder te vergelijken is met kwalitatief dan met kwantitatief onderzoek. ${ }^{5}$ Ook dat is in het medisch onderwijs een relatief nieuw terrein. We kunnen het in een beoordelingsprocedure misschien snel eens worden over de vaststelling 'dat het voldoende is'. Maar weten we dan waar het over gaat? Over welke competenties hebben we het dan? Welke rol spelen de (korte) klinische beoordelingen daarbij? En waar ligt het referentiepunt? Aan het eind van een opleiding?

Al deze vragen maken één ding duidelijk: voor onderzoekers van medisch onderwijs is portfolio nog een groot, vrijwel braakliggend onderzoeksterrein. Velen van ons staan al in de steigers om mee te bouwen aan de theorievorming over de onderwijskundige waarde van het portfolio. Het is goed om, voor we beginnen, nog even na te denken over de constructie van het bouwwerk. Henk Schmidt heeft ons op het AMEE-congres in Amsterdam (2005) daarover aan het denken gezet. Hij betoogde dat veel onderzoek van medisch onderwijs zich op een descriptief niveau bevindt of de functie vervult om gemaakte keuzes te verantwoorden (justification). Bij dit type onderzoek worden verschillen tussen de oude en de nieuwe situatie gevonden. Het probleem is echter dat vaak onbekend is waar het gevonden verschil door veroorzaakt wordt. Slechts op zeer beperkte schaal wordt verklarend onderzoek gedaan (clarification). Dan gaat het bijvoorbeeld om de vraag: wat gebeurt er met de student tijdens het leren? Bij onderzoek naar de leereffecten van portfolio is ook behoefte aan verklarend onderzoek. En, beste collegae, dergelijk onderzoek is mijns inziens de beste manier om bij uitbraak van portfoliose een ophokplicht voor medisch onderwijskundigen te voorkomen.

\section{Janke Cohen-Schotanus}

\section{Literatuur}

1. Rees C. The use (and abuse) of the term 'portfolio'. Med Educ 2005;39(4):436-7.

2. Friedman ben David M, Davis MH, Harden RM, Howie PW, Ker J, Pippard MJ. AMEE Medical Education Guide No. 24: Portfolios as a method of student assessment. Med Teach 2001;23(6):53551.

3. Beullens J, Deketelaere A, Struyf E. Literatuuronderzoek naar de houding tegenover de psychometrische kwaliteit van portfolio's in het medisch onderwijs. Tijdschrift voor Medisch Onderwijs 2004;23(4):186-95.

4. Cohen-Schotanus J. Student assessment and examination rules. Med Teach 1999;21(3):318-21.

5. Driessen E, Vleuten $C$ van der, Schuwirth L, Tartwijk J van, Vermunt J. The use of qualitative research criteria for portfolio assessment as an alternative to reliability evaluation: a case study. Med Educ 2005;39(2):214-20. 